\title{
Anita Filipczak-Białkowska*
}

\section{Luka informacyjna jako czynnik wyzwalający zaciekawienie odbiorcy (na podstawie analizy nagłówków artykułów zamieszczonych w wybranych portalach internetowych) ${ }^{1}$}

\section{Wstęp}

Różnorodne koncepcje proponują wprowadzenie kategorii ilości do rozważań nad pojęciem informacji. Na przykład, według koncepcji skąpca poznawczego ludzie mają ograniczoną możliwość przetwarzania informacji, więc stosują skróty myślowe wszędzie, gdzie to możliwe. Co więcej, wytwarzają różne strategie upraszczania skomplikowanych problemów, które mogą nie być poprawne, a nawet prowadzić do błędnych wniosków, ale zwiększają efektywność działania². Metafora skąpca opiera się na przekonaniu, że jednostka nie jest wewnętrznie motywowana do poszukiwania informacji na temat napotkanych obiektów, że skłonna jest raczej „szukać rozwiązań <<dostatecznych〉> niż optymalnych"3. Koncepcja skąpca poznawczego została zaadaptowana do nauki o mediach w ramach rozważań nad spo-

* Dr, Zakład Teorii i Praktyki Komunikacji, Katedra Dziennikarstwa i Komunikacji Społecznej, Uniwersytet Łódzki, e-mail: anita.filipczak@uni.lodz.pl.

1 Artykuł zredagowany w ramach projektu badawczego pt. Luka informacyjna jako czynnik wyzwalający ciekawość odbiorcy. Zjawisko clickbajtu w internetowych portalach informacyjnych.

2 S.T. Fiske, S.E. Taylor, Social Cognition: From Brains to Culture, New York 2013, S. 15: „[...] people are limited in their capacity to process information, so they take shortcuts whenever they can [...]. People adopt strategies that simplify complex problems; the strategies may not be correct or product correct answers, but they emphasize efficiency".

3 K. Piber-Dąbrowska, G. Sędek, Spostrzeganie bez uprzedzeń i stereotypów - zarys problematyki, „Psychologia Społeczna" 2006, nr 2, s. 7. 


\section{Anita Filipczak-Białkowska}

sobem odbioru przekazu, także do rozważań nad automatyzmami, które kierują naszym codziennym zachowaniem w relacjach społecznych, nazwanych przez Roberta Cialdiniego heurystykami sądzenia ${ }^{4}$.

Z innej perspektywy na ten sam stan rzeczy, tj. nadmiar informacji w środowisku, w którym funkcjonuje człowiek, spogląda ekonomika informacji, dyscyplina w ramach nauk ekonomicznych. Na jej gruncie funkcjonuje pojęcie luki informacyjnej, istotne dla dalszych rozważań podejmowanych w niniejszym artykule, niemniej jednak ekonomika informacji rozumie je w odmienny sposób. Jak przyjmuje Józef Oleński, charakteryzując społeczeństwo informacyjne:

W każdym społeczeństwie, w każdej gospodarce podmioty społeczno-gospodarcze (ludzie, przedsiębiorstwa) do sprawnego działania funkcjonowania w państwie, społeczeństwie, gospodarce potrzebują pewnego minimalnego zasobu informacji. Zasób ten nazywamy „funkcjonalnym minimum”. Wraz z rozwojem społecznym i postępem technicznym minimum to rośnie. Cechą społeczeństwa informacyjnego jest to, że minimum funkcjonalne znacznie przekracza zdolności percepcyjne człowieka. Przekracza ono często zasoby informacyjne oraz możliwości organizacyjne, techniczne i gospodarcze jednostki organizacyjnej. Powstaje więc luka informacyjna między zasobami informacyjnymi podmiotu a jego funkcjonalnym minimum informacyjnym ${ }^{\mathbf{5}}$.

Społeczna luka informacyjna ${ }^{6}$ stanowi, istotną przeszkodę dla funkcjonowania podmiotów w społeczeństwie i blokuje rozwój społeczeństwa informacyjnego.

$\mathrm{Na}$ gruncie psychologii koncepcją luki informacyjnej (ang. information gap) zajmował się m. in. George Loewenstein. Jego praca pt. The Psychology of Curriosity: Review and Reinterpretation ${ }^{7}$ stała się inspiracją do podjęcia rozważań, których efekty przedstawione są poniżej. Zdaniem badacza, luka informacyjna jest podstawowym mechanizmem generującym ciekawość. Powstaje ona, kiedy jednostka uświadamia sobie dziurę, brak w swojej wiedzy, który może być potencjalnie wypełniony odpowiednią informacją. Autor sugeruje, że zaciekawienie jednostki jest stanem stopniowalnym i wskazuje czynniki, które mogą generować silniejsze zainteresowanie określonymi treściami, takie jak osobiste odniesienie do tej jednostki czy potencjalna możliwość wypełnienia kilku luk w wiedzy jedną informacją.

4 Por. R.B. Cialdini, Wywieranie wpływu na ludzi. Teoria i praktyka, przeł. B. Wojciszke, Gdańsk 2004.

5 J. Oleński, Ekonomika informacji. Metody, Warszawa 2003, s. 277.

6 Por. J. Oleński, dz. cyt., s. 24-32, także: T. Galewski, Społeczna luka informacyjna jako bariera rozwoju społeczeństwa informacyjnego „Zeszyty Naukowe Uniwersytetu Szczecińskiego. Studia Informatica" 2014, nr 34, s. 57-67.

7 G. Loewenstein, The Psychology of Curriosity: Review and Reinterpretation, „Psychological Bulletin" 1994, vol. 116, nr 1, s. 75-98. 
Podsumowując przytoczone poglądy o środowisku funkcjonowania współczesnego homo communicans, można powiedzieć, że dzisiejszy odbiorca to skąpiec poznawczy $w$ społeczeństwie informacyjnym. Uwzględniając specyfikę otoczenia informacyjnego, w jakim aktualnie funkcjonuje człowiek, a także ograniczone możliwości poznawcze, jakimi dysponuje, pierwszym najważniejszym zadaniem, jakie musi zrealizować nadawca jest zwrócenie uwagi odbiorcy na komunikat. Niniejszy artykuł przedstawia rozważania na temat funkcji tytułu w kreowaniu zainteresowania odbiorcy artykułem zamieszczonym $\mathrm{w}$ internetowym portalu informacyjnym. Przedstawiona $\mathrm{w}$ nim będzie koncepcja luki informacyjnej jako czynnika wyzwalającego zaciekawienie odbiorcy w ujęciu metodologii gramatyki komunikacyjnej. Następnie zaprezentowane zostaną wyniki badań ankietowych, które zostały przeprowadzone w celu zweryfikowania prawdziwości przyjętej hipotezy.

\section{Uwagą odbiorcy można sterować - założenia metodologiczne}

Mając wzgląd na długą i multidyscyplinarną tradycję badań nad zjawiskiem ciekawości, w niniejszym artykule proponuję przyjrzeć się zagadnieniu z perspektywy pragmatyki językowej. Abstrahując od tego, co zajmowało psychologów, mianowicie, czy ciekawość jest zdolnością powstałą ewolucyjnie, czy jest ona stanem refleksyjnym, cechującym jednostki wybitne, opieram się na ustaleniach psychologii spostrzegania ${ }^{8}$ i przyjmuję założenie, że uwagą odbiorcy w komunikacji internetowej można sterować, a zatem można także wywołać jego zainteresowanie. W miejsce terminu ciekawość trafniejszym określeniem omawianego tu zjawiska wydaje się zaciekawienie. Przez zaciekawienie rozumiem względnie krótkotrwały stan podmiotu, charakteryzujący się generowanym przez bodźce środowiskowe poczuciem braku wiedzy i silną potrzebą natychmiastowej redukcji tego braku. Potrzeba ta stanowi siłę napędzającą do działania. $Z$ przyjętego założenia wynika pytanie badawcze: w jaki sposób zatytułować artykuł zamieszczony w portalu internetowym, aby skłonić odbiorcę do „kliknięcia” i otwarcia tekstu głównego?

Problemem tytułu tekstu szczególnie obszernie zajmowano się na gruncie prasoznawstwa. Literatura przedmiotu dotycząca języka w prasie, ale też samych nagłówków, począwszy od pierwszej monografii nagłówka autorstwa Walerego Pisarka, zatytułowanej Poznać prasę po nagłówkach!9 z 1967 r., jest bardzo obszerna. W znacznej mierze badacze koncentrują się na analizie budowy nagłówków prasy papierowej pod względem językowo-stylistycznym ${ }^{10}$, choć istnieją prace

8 Zob. A. Falkowski, T. Tyszka, Psychologia zachowań konsumenckich, Gdańsk 2009, s. 15-45.

9 W. Pisarek, Poznać prasę po nagłówkach! Nagłówek wypowiedzi prasowej w oświetleniu lingwistycznym, Kraków 1967.

10 Zob. E. Pałuszyńska, Nagłówki w "Gazecie Wyborczej” (ekspresywna leksyka, frazematyka, metaforyka), Łódź 2006; A. Sadowska, Tytuły prasowe - ich budowa i funkcja, „Acta Universitas 
ujmujące problem z innych perspektyw. Do takich należy artykuł Marzeny Makiewicz ${ }^{11}$, w którym autorka zwraca uwagę na innowacje graficzne w nagłówkach prasy papierowej i podkreśla ich funkcję sterowania procesem interpretacji zawartych w nagłówku treści. W literaturze przedmiotu można znaleźć też coraz więcej opracowań dotyczących nagłówków artykułów prasowych zamieszczanych w Internecie ${ }^{12}$. Na szczególną uwagę w kontekście poruszonych tu zagadnień zasługuje artykuł Łukasza Wali pt. Dezinformacja społeczeństwa realizowana przez media internetowe a jej społeczna akceptacja, bowiem stanowi on jakby słowo wstępne do rozważań w dalszej części niniejszego tekstu, charakteryzując sytuacje, które stanowiły motywację do podjęcia badań nad mechanizmem zaciekawienia. Autor trafnie kreśli sytuację biznesową wydawcy mediów elektronicznych, który zmuszony jest dbać o dużą liczbę odsłon poszczególnych stron - to bowiem zapewnia mu dochody od reklamodawców:

Odmiennie [...] [niż w przypadku gazet papierowych - AFB] wygląda model sprzedaży reklam - zwykle płaci się za odsłony (z ang. views, CMP - cost per mille, czyli za tysiąc wyświetleń) oraz za kliknięcia w reklamy (z ang. clicks, CPC - cost per click). Prowadzi to do sytuacji niekomfortowej dla wydawcy: albo zachęci nagłówkiem do $<<$ przeczytania > całego artykułu, albo nie zarobi na wyświetleniu reklamy, a tym bardziej na kliknięciu w nią [...]. Słowo <<przeczytania > zostało ujęte w cudzysłów celowo - czytanie nie ma tutaj nic do rzeczy, ponieważ liczy się w zasadzie tylko wejście na podstronę $\mathrm{z}$ artykułem"13.

Następnie Wala zwraca uwagę na szczególną rolę nagłówka w przedstawionym procesie czerpania zysków wydawcy z publikowanych treści:

[...] Wydawca musi dostarczyć takich treści, które będą zachęcały czytelnika do wejścia na strony, na których będą umieszczone. Z kolei nagłówki stają się swoistą

Lodziensis. Folia Polonica” 2007, nr 9, s. 401-413; B. Grochala, Dowcip językowy w nagłówkach „Gazety Wyborczej”, „Acta Universitas Lodziensis. Folia Linguistica” 2005, nr 43, s. 25-35 i in.

11 M. Makiewicz, Innowacja graficzna jako składnik wizualizacji semantyki w nagłówkach „Gazety Wyborczej”, „Acta Universitas Lodziensis. Folia Linguistica” 2007, nr 44, s. 87-103.

12 I. Pawłowska, Nagłówek w sieci: budowa i funkcja nagłówków prasowych na przykładzie internetowego portalu miejskiego e-sosnowiec.pl, „Rocznik Prasoznawczy” 2010, nr 4, s. 105-118; M. Kasiak, Artykuł publicystyczny w prasie i w Internecie. Analiza porównawcza, „Rocznik Bibliologiczno-Prasoznawczy” 2016, t. 8/19, s. 189-206; Ł. Wala, Dezinformacja społeczeństwa realizowana przez media internetowe a jej społeczna akceptacja, „Annales. Etyka w Życiu Gospodarczym" 2015, t. 18, nr 1, s. 115-124.

13 Ł. Wala, dz. cyt., s. 118. 
reklamą tych treści. Albo sprzedadzą ją w taki sposób, że użytkownik ją <<kupi >> i jej wyświetlenie zostanie zaliczone, albo dany portal nie zarobi ${ }^{14}$.

Przedmiotem dalszych rozważań autora cytowanego artykułu jest ocena etyczności opisanych działań wydawców mediów internetowych: „Poprzez nieprecyzyjne nagłówki oraz inne zabiegi wydawcy w prowadzają czytelników w błąd, świadomie ograniczając wolność czytelnika, co jest działaniem nieetycznym"15. Perspektywa etyki w kontekście omawianego zjawiska nie będzie przedmiotem mojego zainteresowania, warto jednak polecić ten aspekt głębszej refleksji Czytelnika. Skoncentruję się jedynie na mechanizmie powodującym nieprecyzyjność. Przyjmuję, że jest ona zamierzonym działaniem, powstrzymuję się jednak od oceny jego skutków w wymiarze etycznym.

Nieprecyzyjność to właściwość komunikatu w ogóle, nie jest ona specyficzną cechą nagłówków prasowych. Podstawowym celem stosowania nieprecyzyjnych komunikatów jest natomiast doprowadzenie do powstania u odbiorcy luki informacyjnej, która jest wyzwalaczem zaciekawienia:

nieprecyzyjny komunikat $\rightarrow$ luka informacyjna $\rightarrow$ zaciekawienie

Metodologia tradycyjnych badań prasoznawczych nie pozwala na opisanie mechanizmu generowania luki informacyjnej, dlatego w niniejszym artykule przyjmuję perspektywę metodologiczną gramatyki komunikacyjnej Aleksego Awdiejewa i Grażyny Habrajskiej ${ }^{16}$. Poniżej przedstawione zostaną w sposób syntetyczny założenia metodologiczne komunikatywizmu, na podstawie których sformułowałam hipotezę badawczą, a następnie zaprezentowana zostanie sama hipoteza.

\section{Podstawowe założenia komunikatywizmu}

Jednym z aksjomatów komunikatywizmu, jest założenie, że „gramatyka [komunikowania] dzieli się na trzy podstawowe poziomy: ideacyjny, interakcyjny i organizacji dyskursu"17, które współdziałając, tworzą ostateczną postać wypowiedzenia. W założeniu autorów gramatyki komunikacyjnej, każde wypowiedzenie ma zatem określoną formę językową, ale też zawiera obraz ideacyjny (OI) oraz ma przypisany konkretny zamiar komunikacyjny. Obraz ideacyjny odzwierciedla fragment rzeczywistości lub mentalny schemat abstrakcyjny przechowywany w ludzkiej pamię-

14 Tamże, s. 118-119.

15 Tamże, s. 119.

16 A. Awdiejew, G. Habrajska, Wprowadzenie do gramatyki komunikacyjnej, t. 1 i 2, Łask 20042006; ciż, Komponowanie sensu w procesie odbioru komunikatów, Łódź 2010.

17 A. Awdiejew, G. Habrajska, Wprowadzenie do gramatyki komunikacyjnej, t. 1, Łask 2004, s. 15. 
ci. Odwzorowuje on ogólnie przyjęte standardowe wyobrażenia mówiących o standardowych scenariuszach życiowych. Aby można było obraz ideacyjny wykorzystać w procesie komunikacji, nieuniknione jest odniesienie go do rozkładalnej postaci standardu semantycznego, który stanowi intersubiektywną, uogólnioną reprezentację obrazu ideacyjnego o strukturze predykatowo-argumentowej. W systemie językowym zatem obraz ideacyjny występuje jako standard semantyczny, mający strukturę predykatowo-argumentową [P(a)], np. PADAĆ [DESZCZ], LECZYĆ [LEKARZ, PACJENT]. „Na poziomie użycia w konkretnym tekście, jednostki językowe [...] wskazują na pewne typowe sytuacje (typowe stany rzeczy), które w systemie językowym występują jako standardy semantyczne"18. Owe jednostki językowe czy leksemy nie denotują same siebie, ale otwierają dostęp do całego związanego z nimi obrazu ideacyjnego. „Słowo jest tylko hasłem, które wskazuje na pewien standard semantyczny w postaci predykatywnej"19. Wynikająca $z$ kompetencji komunikacyjnej łatwość uruchomienia odpowiednich standardów semantycznych, pozwala w stosunkowo syntetycznej formie przekazać nawet złożone treści.

W tym miejscu w koncepcji gramatyki komunikacyjnej pojawia się pojęcie luki informacyjnej:

Ogólnie rzecz biorąc, proces przekazu informacyjnego w języku naturalnym ma charakter aproksymacyjny, czyli wykazuje względną tolerancję w stosunku do pełności przekazu. Dzieje się tak z dwóch powodów. Po pierwsze [...] mówiący dążą do minimalizacji wysiłku, podając tylko częściową informację o przekazywanych sytuacjach, a po drugie, analizując odwołania wyrazów tekstowych do standardów semantycznych, odbiorca w oparciu o swe nawyki komunikacyjne jest w stanie, jeśli zaistnieje taka potrzeba, odtworzyć brakujące komponenty sensu. Pod względem pełności przekazu w zasadzie każdy komunikat ma charakter niepełny. W uznanym za wystarczający i oczywisty przekazie typu:

Szklanka stoi na stole zauważamy duże luki informacyjne, dotyczące zarówno tła informacyjnego (stół znajduje się wewnątrz jakiegoś pomieszczenia, gdzie również znajduje się obserwator itd.), jak i samego obrazu (szklanka stoi otworem do góry, jest pusta itd.) ${ }^{20}$.

Aproksymacyjny charakter tekstu jest konsekwencją ogólnie przyjętego efektu kontekstowego Dana Sperbera i Deirdre Wilson ${ }^{21}$. Zakłada się w nim, że nadawca powinien przyjąć, iż interlokutor ma taką samą (lub podobną) moc inferencji (wnioskowania konwersacyjnego), czyli taką zdolność rozumienia, jaką ma sam

18 Tamże, s. 22.

19 Tamże, s. 23.

20 A. Awdiejew, G. Habrajska. Komponowanie..., s. 96.

21 Za: A. Awdiejew, Gramatyka interakcji werbalnej, Kraków 2007, s. 70-71. 
nadawca. Dlatego nadawca musi w sposób optymalny wykorzystywać możliwości wnioskowania partnera, aby z jednej strony nie narażać go na niezrozumienie przy zbyt małej informatywności przekazu, a z drugiej strony nie nudzić go przekazywaniem informacji, która już jest w jego dyspozycji lub którą może osiągnąć, włączając dostępny sobie mechanizm inferencji. Jeżeli w czerwcu w Polsce usłyszany zostanie komunikat „Pada”, przeciętny odbiorca nie pomyśli, że chodzi o opad śniegu, ale natychmiast odtworzy standardowy układ predykatowo-argumentowy: PADAĆ [DESZCZ].

Podsumowując, standardy semantyczne umożliwiają typowe rozumienie tekstu, który jest zawsze znaczeniowo niepełny. Zadaniem odbiorcy w procesie interpretacji jest uzyskanie dopełnienia informacyjnego, czyli dopełnienia sensu. Kiedy napotyka on wypowiedzenie „To jest lekarz”, z łatwością wnioskuje o tym, czym ta osoba się zajmuje, bowiem automatycznie uruchamia się w jego głowie typowy standard semantyczny LECZYĆ [LEKARZ, PACJENT]. Elementem wyzwalającym uruchomienie tego standardu jest pojedynczy leksem 'lekarz', odbiorca natomiast na mocy inferencji jest $\mathrm{w}$ stanie uzupełnić niewystępujące w wypowiedzi elementy tego standardu semantycznego.

\section{Hipoteza badawcza}

Po ustaleniu podstawowych założeń metodologicznych można przedstawić hipotezę badawczą, przyjętą na początku projektu badawczego. Hipoteza ta brzmiała:

Komunikaty, które skonstruowane są w oparciu o układy predykatowo-argumentowe charakteryzujące się brakiem danych na temat pierwszego lub drugiego argumentu z układu, generują lukę informacyjną i przez to są postrzegane jako wywołujące większe zaciekawienie niż komunikaty pełne informacyjnie. Przez brak danych rozumieć należy brak dostatecznej informacji umożliwiającej dopełnienie sensu zawartego w komunikacie.

Przyjmuje się tu, zgodnie z praktyką komunikacyjną, że uzupełnienie brakujących elementów układu predykatowo-argumentowego we właściwy sposób, tj. zgodny z zamierzeniem nadawcy, nie zawsze jest możliwe. Czasem odbiorca na podstawie zaproponowanej wypowiedzi nie może ustalić, o który standardowy układ predykatowo-argumentowy chodzi, innym razem uzupełnia go innymi argumentami, niż te, które zamierzył sobie nadawca. Ta sytuacja komunikacyjna uniemożliwia operację dopełnienia sensu, a przez to zniesienia luk informacyjnych, jakie generuje komunikat. I to właśnie jest podstawową przyczyną wywołującą zaciekawienie odbiorcy:

$$
\text { zniesienie luki informacyjnej } \rightarrow \text { dopełnienie }
$$

brak możliwości dopełnienia sensu $\rightarrow$ brak możliwości zniesienia luki informacyjnej $\rightarrow$ zaciekawienie $\rightarrow$ poszukiwanie informacji w celu dopełnienia sensu 
Istotnym elementem dociekań pragmatycznych jest pytanie o intencję działania - przyjmuje się zatem, że pojawiające się w środkach masowego przekazu komunikaty mające właściwość generowania luki informacyjnej są konstruowane przez nadawców w sposób zamierzony, nie powstają przez przypadek. Nie wynikają z braku kompetencji nadawcy, ale z dobrej znajomości mechanizmów wywierania wpływu społecznego. Ta „wadliwość tytułów artykułów zamieszczanych w portalach internetowych ma określony cel perswazyjny - jest obliczona na wywołanie zaciekawienia odbiorcy i w następstwie nakłonienia go do kliknięcia i otwarcia odpowiedniego tekstu. Doskonale zilustrował to Wala w cytowanym już artykule ${ }^{22}$. Udało mu się uchwycić moment, kiedy tytuł pełny informacyjnie został zamieniony na komunikat generujący lukę informacyjną (Rysunek 1).

Rysunek 1. Gazeta.pl - zmiana treści nagłówka w czasie

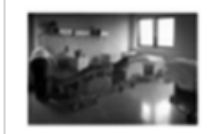

NOWE Kanada: pacjent z

objawami gorączki Ebola

trafit do szpitala. Jest w

stanie krytycznym

52 minuty temu

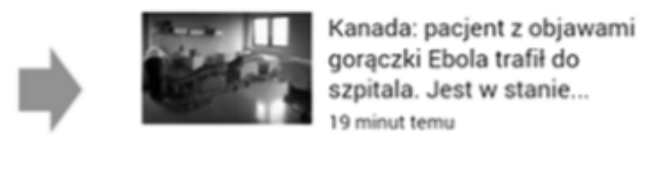

Źródło: zrzut ekranu ze strony głównej portalu Gazeta.pl, wersja mobilna [online] (data dostępu: 25.03.2014, godzina 11:35 oraz godzina 12:08). Opracowanie własne.

\section{Rysunek 1}

Źródło: $Ł$. Wala, Dezinformacja społeczeństwa realizowana przez media internetowe a jej społeczna akceptacja, „Annales. Etyka w życiu gospodarczym” 2015, t. 18, nr 1, s. 119.

\section{Materiał badawczy}

$\mathrm{W}$ ujęciu pragmatycznym luka informacyjna rozpatrywana jest tu w skali mikro (w przeciwieństwie do sposobu ujmowania jej w ekonomice informacji), co oznacza, że przedmiotem zainteresowania w niniejszym tekście są pojedyncze akty mowy.

Materiał badawczy stanowił zbiór tytułów artykułów zamieszczonych na portalach Wirtualna Polska (wp.pl), Rzeczpospolita (rp.pl), Onet (onet.pl) oraz Tlen (o2.pl), widocznych dla odbiorcy podczas wyświetlenia głównej strony portalu. Materiał w przeważającej części zbierany był w okresie luty - wrzesień 2017 r., sporadycznie uzupełniany późniejszymi ciekawymi przykładami.

Warto w tym miejscu uporządkować terminologię dotyczącą charakterystyki materiału badawczego, a dokładnie - ustalić relację między ty tułem a nagłówkiem, nie są to bowiem pojęcia tożsame. Termin nagłówek ma długą tradycję w rozważa-

22 Ł. Wala, dz. cyt. 
niach na temat prasy i wydaje się bardziej fortunny, choć w tradycji badań prasoznawczych terminy te stosowane są zamiennie. W niniejszym artykule nagłówek rozumiany jest jako termin szerszy niż tytuł. Nagłówek potencjalnie może mieć rozbudowaną strukturę - składać się na nią mogą nadtytuł, tytuł główny (czasem nazywany ty tułem właściwym ${ }^{23}$ ), podtytuł, przy czym obligatoryjny jest tylko tytuł główny. Właśnie on stanowi przedmiot przedstawionego tu badania i stosując dalej określenie tytuł, odnoszę się właśnie do tej części nagłówka.

Materiał badawczy był zróżnicowany tematycznie. Aby wyeliminować taką zmienną jak zakres zainteresowań badanych, zadbano o to, aby poszczególne pozycje w ankiecie były zróżnicowane pod względem tematyki: były to przykłady zaczerpnięte z sekcji portalu, poświęconych zagadnieniom sportu, zdrowia, aktualnej sytuacji społeczno-politycznej, świata show-biznesu i innych.

\section{Językoznawcza metoda badawcza - charakterystyka i przebieg I etapu badania}

W pierwszym etapie przeprowadzono badania językowe. Zgodnie z przyjętą metodologią gramatyki komunikacyjnej, tytuły artykułów zanalizowane zostały pod kątem eksponowania bądź ukrywania argumentów w zastosowanym układzie predykatowo-argumentowym. Zauważono, że część tytułów nie zawiera informacji, które pozwoliłyby wypełnić miejsce pierwszego lub drugiego argumentu w układzie. Ponieważ uznaje się kreowanie komunikatu za proces intencjonalny (jego twórca jest - w założeniu - profesjonalistą), przyjęto, że w części tytułów brak argumentów był zamierzony, zatem wybrane argumenty nie były eksponowane celowo - były ukrywane. Co więcej, brak tych argumentów uniemożliwiał przeprowadzenie operacji dopełnienia sensu. Jest to szczególnie ważne i łatwe do wykorzystania w gatunkach tekstów, które mają wysoko nasiloną właściwość wnoszenia nowej wiedzy - portale informacyjne, przez wysoką aktualność publikowanych treści, do takich właśnie należą.

Luka informacyjna to efekt procesu interpretacji, powstający wówczas, gdy pojawia się przestrzeń między wiedzą niezbędną do przeprowadzenia operacji dopełnienia sensu w procesie interpretacji komunikatu a wiedzą już posiadaną przez odbiorcę (jego bazą interpretacyjną), która to przestrzeń nie może zostać uzupełniona bez wprowadzenia dodatkowych danych. Luka informacyjna może uniemożliwiać rekonstrukcję sensu, może też powodować dużą rozbieżność między reprezentacją kognitywną nadawcy i reprezentacją kognitywną odbiorcy. Może być efektem przypadkowym, ale jej wytworzenie może też zostać zamierzone przez nadawcę.

23 Por. A. Sadowska, dz. cyt. 


\section{Anita Filipczak-Białkowska}

Bazę interpretacyjną odbiorcy tworzy posiadana przez niego wiedza oraz informacje udostępniane przez nadawcę w danym komunikacie. Perspektywa badacza nie daje dostępu do informacji na temat zakresu wiedzy odbiorcy, dlatego można tylko założyć, że jest to wiedza ogólna przeciętna, na porównywalnym poziomie u wszystkich odbiorców, choć należy pamiętać, że jest to duże uproszczenie.

Podstawą do podziału zebranego materiału badawczego była ilość danych zawartych w tytule, pozwalających na wypełnienie pierwszego i drugiego argumentu. Na tej podstawie wyselekcjonowano tytuły, które zapewniały dopełnienie sensu i takie, które tę operację uniemożliwiały. Poniżej przedstawione są przykłady należące do każdej z grup, aby zilustrować przyjęty tok rozumowania.

Do kategorii tytułów pełnych informacyjnie, czyli nie generujących luki informacyjnej, zalicza się poniższy przykład:

(1) Grzegorz Łapanowski i Magdalena Święciaszek wzięli ślub (źródło: wp.pl, dostęp: 13.09.2017),

który uruchamia standard semantyczny:

POŚLUBIĆ [KTO? KOGO?].

W oparciu o dane zawarte w tytule z przykładu nr 1 możliwe jest uzupełnienie argumentów w przywołanym dwuargumentowym układzie predykatowo-argumentowym:

\section{POŚLUBIĆ [G. ŁAPANOWSKI, M. ŚWIĘCIASZEK]}

i w efekcie osiągnięcie dopełnienia sensu dla tego komunikatu.

Podobnie w przykładzie nr 2:

(2) Chrissy Teigen przyznała się do problemów z alkoholem (źródło: wp.pl, dostęp: 27.08.2017).

Przykład ten jest nieco bardziej skomplikowany, bowiem uruchamia scenariusz:

t-2 NADUŻYWAĆ [KTO? CZEGO?]

t-1 PRZYZNAĆ SIĘ [KTO? DO CZEGO?].

W oparciu o tytuł artykułu odbiorca może jednak z łatwością osiągnąć poziom dopełnienia sensu dla tej wypowiedzi: 
t-2 NADUŻYWAĆ [C. TEIGEN, ALKOHOL]

t-1 PRZYZNAĆ SIĘ \{C. TEIGEN, NADUŻYWAĆ [C. TEIGEN, ALKOHOL]\}.

W przykładzie nr 3 :

(3) Zakończyło się spotkanie Kaczyńskiego $z$ May (źródło: wp.pl, dostęp: 23.03.2017),

także pojawia się scenariusz:

t-2 SPOTKAĆ SIĘ [KTO, Z KIM]

t-1 ZAKOŃCZYĆ SIĘ [CO?],

który można uzupełnić brakującymi argumentami:

t-2 SPOTKAĆ SIĘ [J. KACZYŃSKI, (Z) TH. MAY]

t-1 ZAKOŃCZYĆ SIĘ [\{SPOTKANIE > SPOTKAĆ SIĘ [J. KACZYŃSKI, (Z) TH. MAY]\}.

Wiele tytułów artykułów zamieszczanych w portalach internetowych to jednak komunikaty, które generują lukę informacyjną. Przykładem może być tytuł $\mathrm{nr}(4)$ :

(4) Wielka kłótnia w studiu. Poszło o Smoleńsk i Tuska (źródło: wp.pl, dostęp: 24.10.2017),

który przywołuje standard semantyczny:

KŁÓTNIA > KŁÓCIĆ SIĘ [KTO? Z KIM? O CO?].

W oparciu o dane zawarte w wypowiedzi wiadomo tylko, co było przedmiotem kłótni, niemożliwe jest jednak uzupełnienie informacji na temat aktantów - nie wiadomo między jakimi osobami doszło do kłótni. Ostatecznie więc wszystko, co odbiorca może ustalić, to układ predykatowo-argumentowy w następującej postaci:

KŁÓCIĆ SIĘ [KTO? Z KIM? (O) SMOLEŃSK] \& KŁÓCIĆ SIĘ [KTO? Z KIM? (O) D. TUSK]

Dane brakujące do uzupełnienia pierwszego i drugiego argumentu w powyższym układzie predykatowo-argumentowym można uzyskać po kliknięciu w link i przeniesienie się na podstronę z tekstem głównym. 
Przykład nr 5:

(5) Mąż ofiary katastrofy smoleńskiej oskarża (źródło: wp.pl, dostęp: 24.02.2017)

przywołuje standard semantyczny:

OSKARŻAĆ [KTO? KOGO? O CO?],

który można uzupełnić tylko niewieloma danymi, otrzymując w efekcie układ predykatowo-argumentowy w postaci:

\section{OSKARŻAĆ [MĄŻ OFIARY KATASTROFY SMOLEŃSKIEJ, KOGO? O CO?].}

W układzie tym brakuje danych dla drugiego argumentu, pozornie też tylko mamy wiedzę na temat argumentu pierwszego. Sformułowanie „mąż ofiary katastrofy smoleńskiej” zawęża nieco zakres brakującej wiedzy, nadal jednak nie można osiągnąć dopełnienia sensu. W wydarzeniu, o którym mowa w przykładzie zginęły bowiem 24 kobiety, zatem nie łatwo ustalić, o kogo dokładnie może chodzić $\mathrm{w}$ artykule.

Przykład kolejny:

(6) Koniec wciskania kitu. Będą słone kary (źródło: wp.pl, dostęp: 12.09.2017)

przywołuje standardy semantyczne:

WCISKAĆ KIT [KTO? KOMU?] > OKŁAMYWAĆ [KTO? KOGO?] KARA > KARAĆ [KTO? KOGO? ZA CO?],

w tytule jednak nie ma żadnych danych, którymi można byłoby uzupełnić pozycję pierwszego i drugiego argumentu. Warto zwrócić tutaj uwagę na szczególną rolę negatywnego wartościowania, jakim obudowany jest zaproponowany obraz ideacyjny. Można przypuścić, że wartościowanie to pełni rolę wspomagającą, kreuje dodatkowe napięcie, które nasila potrzebę redukcji niewiedzy, czyli uzyskania dopełnienia sensu dla komunikatu.

Obudowany negatywnym wartościowaniem jest także tytuł z przykładu nr 7:

(7) Ambasador RP w KRLD: obawiam się (źródło: wp.pl, dostęp: 13.09.2017).

Można tu w przywołanym standardzie semantycznym:

OBAWIAĆ SIĘ [KTO? CZEGO?] 
uzupełnić tylko pierwszy argument, uzupełnienie drugiego byłoby zapewne możliwe dopiero po otwarciu podstrony z tekstem głównym.

W przeciwnym tonie, nieco żartobliwym, wyrażony jest tytuł z przykładu nr 8:

(8) Zatrzymała ruch na autostradzie. Postanowiła pospacerować (źródło: wp.pl, dostęp: 12.09.2017),

w którym dochodzi do kontaminacji dwóch standardów semantycznych, z których jeden otwierany jest przez leksem „spacerować”:

SPACEROWAĆ [KTO? GDZIE?],

drugi zaś przez leksem „autostrada”:

SZYBKO> JEŹDZIĆ [SAMOCHODY, (PO) AUTOSTRADA].

W osiągniętym w wyniku tej kontaminacji obrazie ideacyjnym, który można wyrazić układem predykatowo-argumentowym:

SPACEROWAĆ [KTO? (PO) AUTOSTRADA]

nie można uzyskać dopełnienia sensu, bowiem nie ma danych na temat aktanta, z drugiej strony zaś jego kuriozalny charakter (powstający na skutek zderzenia powolnego sposobu poruszania się podczas spaceru i szybkiego ruchu samochodów na autostradzie) stanowi dodatkowy bodziec do rozwikłania zagadki, czyli usunięcia luki informacyjnej.

Podsumowując, zastosowanie metodologii gramatyki komunikacyjnej Awdiejewa i Habrajskiej do analizy materiału badawczego pozwoliło wyselekcjonować tytuły, które mają zdolność generowania luki informacyjnej i jako takie - zgodnie z hipotezą badawczą - powinny wzbudzać większe zaciekawienie odbiorcy.

\section{Badanie ankietowe - charakterystyka i przebieg II etapu badania}

Celem badania ankietowego była empiryczna weryfikacja założenia o pragmatycznej funkcji komunikatów generujących lukę informacyjną. Przyjęto, że w wynikach będzie można zaobserwować nadreprezentację wyboru tytułów, które generują lukę informacyjną w stosunku do tych, które umożliwiały osiągnięcie dopełnienia sensu.

W oparciu o zebraną bazę tytułów generujących lukę i pełnych informacyjnie stworzona została ankieta, która obejmowała 40 pozycji. 20 pozycji stanowiły tytuły pełne informacyjnie, 20 - tytuły mające potencjał wygenerowania luki infor- 
macyjnej. Zadbano o ich zróżnicowanie tematyczne oraz o względną wymienność, tj. np. A-A-A-B-A-B-B-... itp. przy czym A to tytuły umożliwiające dopełnienie sensu, B - tytuły niepełne informacyjnie. Polecenie dla badanych brzmiało: „Poniżej przytoczono tytuły artykułów zamieszczonych w portalach internetowych. Proszę zaznaczyć, który artykuł kliknąłby Pan/kliknęłaby Pani, aby dowiedzieć się więcej".

Ankieta w postaci papierowej została rozdana respondentom, którymi byli studenci I roku dziennikarstwa i komunikacji społecznej UŁ I i II stopnia. Łącznie zebrano 54 ankiety, przy czym do ostatecznego liczenia wyników zakwalifikowano 50. W pozostałych czterech ankietach zaznaczono poniżej pięciu pozycji, co znacznie odbiegało od przeciętnie wskazywanej ich liczby (12-14 pozycji) i można było wnioskować, że ci respondenci nie wykazali dostatecznego zaangażowania $\mathrm{w}$ wykonanie polecenia badawczego.

Łącznie respondenci wskazali 640 pozycji, z czego niemal 41\% stanowiły komunikaty pełne informacyjnie, nieco ponad 59\% - tytuły z luką informacyjną. Różnica wyniosła około 18\% na korzyść komunikatów generujących lukę informacyjną i należy ją uznać za różnicę znaczącą, potwierdzającą prawdziwość przyjętej hipotezy.

Aby wykluczyć działanie takiej zmiennej, jak wpływ kolejności pojawiania się pozycji $\mathrm{w}$ ankiecie na zasadzie: na początku czytania większe zaangażowanie, na końcu mniejsze, przeprowadzono kolejne badanie na mniejszej grupie liczącej 30 osób, do którego przygotowano wersję B ankiety. Charakteryzowała się ona odwróconą kolejnością tytułów, tj. ten, który w wersji A występował jako pierwszy, w wersji B był ostatni i dalej odpowiednio.

Tutaj również ujawniły się znaczne dysproporcje w preferencjach respondentów na korzyść komunikatów generujących lukę informacyjną.

\section{Wnioski}

Zgodnie z zaproponowaną $\mathrm{w}$ niniejszym artykule definicją, luka informacyjna to pojawiający się $\mathrm{w}$ procesie interpretacji efekt zachodzący wówczas, gdy powstaje przestrzeń między wiedzą niezbędną do przeprowadzenia operacji dopełnienia sensu w procesie interpretacji komunikatu a wiedzą już posiadaną przez odbiorcę (jego bazą interpretacyjną). Przestrzeń ta, niekorzystna z punktu widzenia odbiorcy, nie może zostać uzupełniona bez wprowadzenia dodatkowych danych. Taki stan rzeczy może być z kolei korzystny dla nadawcy, a nawet przez niego zaprojektowany - nadawca może w ten sposób sterować działaniem odbiorcy w kierunku poszukiwania przez tego ostatniego dodatkowych informacji, które pozwolą zapełnić lukę informacyjną i osiągnąć dopełnienie sensu w procesie interpretacji. Mechanizm ten może mieć zastosowanie między innymi w dydaktyce, choć może też budzić wątpliwości etyczne, na przykład wówczas, kiedy wykorzystywany jest w tworzeniu nagłówków 
artykułów zamieszczanych w portalach informacyjnych. W tym artykule przyjmuje się stanowisko, że mechanizm generowania luki informacyjnej nie podlega ocenie pod względem etycznym.

Badanie zebranego materiału językowego, przeprowadzone w oparciu o metodologię gramatyki komunikacyjnej, pozwoliło zidentyfikować tytuły artykułów, które obarczone były luką informacyjną i odróżnić je od komunikatów pełnych informacyjnie. Wyniki analizy językowej pozwoliły sporządzić ankietę, na podstawie której poddano weryfikacji przyjętą hipotezę badawczą. Hipoteza stanowiła, że komunikaty, które skonstruowane są zgodnie z modelem układu predykatowo-argumentowego charakteryzującego się brakiem danych na temat pierwszego lub drugiego argumentu z tego układu, generują lukę informacyjną i przez to są postrzegane jako wywołujące większe zaciekawienie niż komunikaty pełne informacyjnie.

Ankieta przeprowadzona była wśród studentów I i II stopnia w dwóch turach. W pierwszej turze badaniem objęto grupę 50 studentów, w drugiej - 30. Zarówno wyniki uzyskane w pierwszej, jak i w drugiej turze ujawniły, że większym zainteresowaniem cieszyły się tytuły, które generowały lukę informacyjną. Przyjęta hipoteza badawcza została zatem potwierdzona w badaniu.

Uzyskane wyniki zachęcają do kontynuowania badań nad zagadnieniem, do zbadania dodatkowych aspektów, które wydają się mieć wpływ na generowanie zaciekawienia odbiorcy. Należy do nich emocjonalne zabarwienie komunikatu, towarzyszące generowaniu luki informacyjnej. Wydaje się także, że można odtworzyć pewne konstrukcje, w oparciu o które tworzone są tytuły generujące lukę informacyjną. Jest to zatem temat o dużym potencjale badawczym i wysokiej istotności społecznej.

\section{Bibliografia}

Awdiejew A., Gramatyka interakcji werbalnej, Kraków 2007.

Awdiejew A., Habrajska G., Wprowadzenie do gramatyki komunikacyjnej, t. 1, Łask 2004. Awdiejew A., Habrajska G., Wprowadzenie do gramatyki komunikacyjnej, t. 2, Łask 2006. Cialdini R.B., Wywieranie wptywu na ludzi. Teoria i praktyka, przeł. B. Wojciszke, Gdańsk 2004.

Falkowski A., Tyszka T., Psychologia zachowań konsumenckich, Gdańsk 2009, s. 15-45. Filipczak-Białkowska A., Strategies for Organising the Attention of Receivers in E-mail Marketing, „Acta Universitas Lodziensis. Folia Litteraria Polonica” 2017, nr 5(43), s. 159-171.

Fiske S.T., Taylor S.E., Social Cognition: From Brains to Culture, New York 2013.

Galewski T., Społeczna luka informacyjna jako bariera rozwoju społeczeństwa informacyjnego, „Zeszyty Naukowe Uniwersytetu Szczecińskiego. Studia Informatica” 2014, nr 34, s. 57-67. 
Grochala B., Dowcip językowy w nagłówkach „Gazety Wyborczej”, „Acta Universitas Lodziensis. Folia Linguistica" 2005, nr 43, s. 25-35.

Kasiak M., Artykuł publicystyczny w prasie i w Internecie. Analiza porównawcza, „Rocznik Bibliologiczno-Prasoznawczy” 2016, t. 8/19, s. 189-206.

Loewenstein G., The Psychology of Curriosity: Review and Reinterpretation, „Psychological Bulletin" 1994, vol. 116, no. 1, s. 75-98.

Makiewicz M., Innowacja graficzna jako składnik wizualizacji semantyki w nagłówkach „Gazety Wyborczej”, „Acta Universitas Lodziensis. Folia Linguistica” 2007, nr 44, s. 87-103.

Oleński J., Ekonomika informacji. Metody, Warszawa 2003.

Pałuszyńska E., Nagłówki w „Gazecie Wyborczej” (ekspresywna leksyka, frazematyka, metaforyka), Łódź 2006.

Pawłowska I., Nagłówek w sieci: budowa i funkcja nagłówków prasowych na przykładzie internetowego portalu miejskiego e-sosnowiec.pl, „Rocznik Prasoznawczy” 2010, nr 4, s. 105-118.

Piber-Dąbrowska K., Sędek G., Spostrzeganie bez uprzedzeń i stereotypów - zarys problematyki, „Psychologia Społeczna” 2006, nr 2, s. 7-12.

Pisarek W., Poznać prasępo nagłówkach! Nagłówek wypowiedzi prasowej w oświetleniu lingwistycznym, Kraków 1967.

Sadowska A., Tytuly prasowe - ich budowa i funkcja, „Acta Universitas Lodziensis. Folia Polonica" 2007, nr 9, s. 401-413.

Wala Ł., Dezinformacja społeczeństwa realizowana przez media internetowe a jej społeczna akceptacja, „Annales. Etyka w życiu gospodarczym” 2015, t. 18, nr 1, s. 115-124.

\title{
Luka informacyjna jako czynnik wyzwalający zaciekawienie odbiorcy (na podstawie analizy nagłówków artykułów zamieszczonych w wybranych portalach internetowych)
}

\author{
Streszczenie
}

$\mathrm{W}$ artykule przyjmuje się, że luka informacyjna to pojawiający się w procesie interpretacji efekt, powstający wówczas, gdy tworzy się przestrzeń między wiedzą niezbędną do przeprowadzenia operacji dopełnienia sensu w procesie interpretacji 
komunikatu a wiedzą już posiadaną przez odbiorcę (jego bazą interpretacyjną). Ta przestrzeń może być niekorzystna z punktu widzenia odbiorcy, ale korzystna dla nadawcy. Jest to bowiem mechanizm, który pozwala nadawcy sterować działaniem odbiorcy w kierunku poszukiwania przez tego ostatniego dodatkowych informacji, które pozwolą zapełnić lukę informacyjną.

W artykule testuje się hipotezę, że komunikaty charakteryzujące się określoną konstrukcją generują lukę informacyjną i przez to są postrzegane jako wywołujące większe zaciekawienie niż komunikaty pełne informacyjnie. Przedstawione są także rezultaty przeprowadzonego przez autorkę badania językowego oraz sporządzonej na potrzeby badania ankiety. Przyjęta hipoteza badawcza została potwierdzona w badaniu - większym zainteresowaniem cieszyły się tytuły, które generowały lukę informacyjną.

Słowa kluczowe: luka informacyjna, wywieranie wpływu, ciekawość, nagłówek prasowy

\section{Information Gap as the Factor of Realising Receivers Curiosity (According to Headlines of Articles Published on Selected Web Portals)}

Sum mary

Information gap is the effect of interpretation appeared when rises the space between receivers knowledge needed to understand the communicate and the knowledge that receiver already has (his interpretative base). This space could be unfavourable for the receiver, but beneficial for the sender. The mechanism helps him to navigate receivers behaviour for seeking additional information, that will help the last to fill unpleasant information gap.

In the article is being tested the hypothesis that utterances constructed in special way could generate information gap and because of that, they could release higher curiosity than utterances full of information needed to understand the meaning of the utterance. According to the results of language analysis the survey was held. Results of questionnaire validated the hypothesis - more interesting are this utterances that could generate information gap.

Keywords: information gap, social impact, curiosity, headline, press 
Anita Filipczak-Białkowska jest doktorem językoznawstwa. Pracuje w Zakładzie Teorii Praktyki Komunikacji przy Katedrze Dziennikarstwa i Komunikacji Społecznej Uniwersytetu Łódzkiego. Napisała rozprawę doktorską pt. Manifestowanie orientacji ideologicznej $w$ dyskursie politycznym. Jej zainteresowania badawcze skoncentrowane są wokół nauki o komunikowaniu, ze szczególnym uwzględnieniem perspektywy językoznawczej i psychologicznej. Specjalizuje się w problematyce wywierania wpływu na ludzi w różnych typach dyskursu. 